\title{
A Study on Constraints Faced by Self Help Groups in Imphal East District of Manipur
}

\author{
Talsia Mangsidam ${ }^{1 *}$, Aheibam Tarajit Singh ${ }^{2}$ and Geetu Thokchom ${ }^{1}$ \\ ${ }^{1}$ Department of Agricultural Extension \& Communication, Pandit Deen Dayal Upadhyay \\ Institute of Agricultural Sciences, Utlou, Bishnupur, Manipur, India \\ ${ }^{2}$ KVK Utlou, Bishnupur, Manipur, India \\ *Corresponding author
}

\section{A B S T R A C T}

\section{Keywords}

Constraints faced, Self help groups

\section{Article Info}

Accepted:

15 October 2020 Available Online:

10 November 2020
This study was conducted in Imphal East district of Manipur to study the constraints faced by the self help group members for effective functioning of self help groups. 90 respondents were selected as sample for the study. For collection of data, a structured interview schedule was followed. The findings of the study revealed that the major constraints faced by the women self help groups were high cost of input, non-availability of insurance, low market value, playing dual role as a housewife and a business women, lack of technical help, facing high scrutiny at the hands of banks and other financial institutions, insufficient training programme, lack of knowledge, lack of information sources, lack of accountancy management, non-availability of credit, difficulty in raising finance, lack of command in the implementation of decision, lack of marketing, lack of coordination, tendency of others to underestimate the women's capability, power problem, family problem, problem of more competition and negative social attitude. In order to solve these problems, training programmes should be organised frequently and loans should be provided by the banks at low rate of interest and better market linkage should be given in order to sell their produce.

\section{Introduction}

Women make up 52\% of our country's population. Hence there can be no progress unless their needs and interests are fully met. Women empowerment is critical to the socioeconomic progress of the country. Investing in women's capacity building and empowering them to exercise their choices is not only valuable itself but is also the surest way to contribute to economic growth and overall empowerment as farmers, agricultural workers and entrepreneurs as women constitute the backbone of India's agricultural and rural economy. Empowerment of women is a crucial factor in the eradication of poverty as women are the key contribution to the economic at all levels, women participation combating poverty through both remunerative and non-remunerative work at home and the work place, the formation of self help groups (SHGs) has provided a lot of confidence 
among members of SHGs. Self help group microfinance activities help the poor, women not just obtain loans but also develop habit of savings, credit and investing in micro insurance and money transfer services. Moreover SHGs have significantly empowered poor people especially women in rural areas and help borrowers overcome the problem of lack of collateral. In the present study area, majority of the women participate in income generating activities through self help groups (SHGs) so as to meet their needs. Through income generating activities, the members of women SHGs could attain socioeconomic status than the non-participant member. But, the SHG members faced some constraints while performing their activities to achieve their common goal. This paper highlight the constraints faced by the self help group members for effective functioning of SHGs.

Self help groups intermediated by microcredit have been shown to have positive effects on women, with some of these impacts being ripple effects. They have played valuable roles in reducing the vulnerability of the poor, through asset creation, income and consumption smoothing, provision of emergency assistance and empowering and emboldening women by giving them control over assets and increased self-esteem and knowledge (Zaman, 2001).

Several recent assessment studies have also generally reported positive impacts (Simanowitz and Walker 2002). Kumawat and Bansal (2018) reported that women face problem in joining of self help group in terms of information support, technical support, financial support from the running group. Though the women were enthusiastic in joining the SHG due to lack of assistance they were left idle. Kaur and Sachan (2016) reported that the production problems were found to be most serious problem perceived by the members of three self help groups with the average percentage mean score of 62.5 . It was followed by the family and marketing problems with the average percentage mean score of 58.88 and 50.55 respectively. Bortamuly and khuhly conducted a study on 'Constraints of Self Help Groups (SHGs) in Assam' From the study, 'Poor economic status of land' was considered as mostly faced constraint $(81.67 \%)$ in mobilization land. The major problem faced in labour mobilization was 'High cost of paid labour' (80.00\%), while 'Complex procedure of getting loan' $(90.83 \%)$ was the major problem faced in fund mobilization. Rukhsana, Bose and Singh (2014) revealed that the major constraints faced by women members were lack of formal education, no freedom to take decisions, dominance of group leaders, decision made at administrative level, less cooperation of officials, less profit, travel expenses for disbursement of loan, poor monitoring and technical guidance, inadequate space for enterprise, high cost of raw materials, lack of storage facilities, noncooperation between educated and noneducated people and non-cooperation from family members. Kumar and kavithasri (2017) found that lack of formal education, family responsibilities as their major (personal problem), conflicts, lack of communication skills among the group members in decision making process was the major (social problem), heavy competition is major source of (marketing problem) and insufficient loan as their major (financial problem) among the SHG members in the study area. Sadhu, 2013 observed that the SHGs face various problems such as limited credit, non loan payment by members, difficulty in formulation, high turnover of members and also the information regarding the new schemes and incentives by the government reaches these groups slowly. There is communication gap between the banks and implementing agencies (Quader 
and Hussan, 2013). And Bhagyasree (2014) found that the constraint were inadequate support and training programme and inadequate guidance by organisational officials.

\section{Materials and Methods}

The present study was conducted in Imphal East district of Manipur and purposively selected being the native district of the researcher. Based on the maximum self help groups registered, Sawombung block was selected purposively. From the selected block, four villages were selected randomly. By simple random method, 90 respondents were selected from the selected villages. An interview schedule was developed to be used as a tool for data collection. Two types of data viz., primary and secondary data were collected. The primary data was collected through personal interview from the respondent i.e. women SHGs. The secondary data was procured from various publications, magazines, relevant text books and survey materials. And the collected data from the respondents were scored, tabulated and analysed.

\section{Results and Discussion}

The information regarding the constraints for effective functioning of SHGs are presented in Table 1.

Women are not aware of the basic capabilities and self confidence to encounter and to take challenges and barriers of the present limitations. So, there is urgent need to create awareness regarding it. SHG(s) are the building blocks of organisation for the poor people.

Table.1 Constraints as reported by the members for effective functioning of SHGs

\begin{tabular}{|c|l|c|c|}
\hline SI.No & \multicolumn{1}{|c|}{ Constraints } & Frequency(\%) & Rank \\
\hline 1. & High cost of input & $88(97.77)$ & 1 \\
\hline $\mathbf{2 .}$ & Non-availability of insurance & $80(88.88)$ & 2 \\
\hline $\mathbf{3 .}$ & Low market value & $78(86.66)$ & 3 \\
\hline $\mathbf{4 .}$ & Playing dual role of a housewife and a business women & $77(85.55)$ & 4 \\
\hline $\mathbf{5 .}$ & Lack of technical help & $77(85.55)$ & 5 \\
\hline $\mathbf{6 .}$ & $\begin{array}{l}\text { Facing high scrutiny at the hands of banks and other } \\
\text { financial institutions }\end{array}$ & $74(82.22)$ & 6 \\
\hline $\mathbf{7 .}$ & Insufficient training programme & $70(77.77)$ & 7 \\
\hline $\mathbf{8 .}$ & Lack of knowledge & $68(75.55)$ & 8 \\
\hline $\mathbf{9 .}$ & Lack of information sources & $66(73.33)$ & 9 \\
\hline $\mathbf{1 0 .}$ & Lack of accountancy management & $60(66.66)$ & 10 \\
\hline $\mathbf{1 1 .}$ & Non-availability of credit & $53(58.88)$ & 11 \\
\hline $\mathbf{1 2 .}$ & Difficulty in raising finance & $50(55.55)$ & 12 \\
\hline $\mathbf{1 3 .}$ & Lack of command in the implementation of a decision & $45(50.00)$ & 13 \\
\hline $\mathbf{1 4 .}$ & Lack of marketing & $39(43.33)$ & 14 \\
\hline $\mathbf{1 5}$ & Lack of co-ordination & $30(33.33)$ & 15 \\
\hline $\mathbf{1 6 .}$ & Tendency of others to underestimate a women's capability & $28(31.11)$ & 16 \\
\hline $\mathbf{1 7 .}$ & Power problem & $25(27.77)$ & 17 \\
\hline $\mathbf{1 8 .}$ & Family problem & $15(16.66)$ & 18 \\
\hline $\mathbf{1 9}$ & Problem of more competition & $10(11.11)$ & 19 \\
\hline $\mathbf{2 0 .}$ & Negative social attitude & $7(7.77)$ & 20 \\
\hline
\end{tabular}


The present study attempts to find out the constraints faced by SHG members for effective functioning of self help groups SHG(s). Table 1 indicates that more the percentage of the respondents against a particular problem higher are the rank. It was found that $97.77 \%$ of the respondents complained of the 'high cost of input'. About $88.88 \%$ of the respondents complained the 'non-availability of insurance' and $86.66 \%$ faced 'low market value'. $85.55 \%$ of the respondents faced the problem of 'playing dual role of a housewife and a business women', also $85.55 \%$ of the respondents faced 'lack of technical help'. $82.22 \%$ of the respondents complained of 'facing high scrutiny at the hands of banks and other financial institutions' and $77.77 \%$ of the respondents faced 'insufficient training programme'. 'Lack of knowledge' was faced by $75.55 \%$ of the respondents, 'lack of information sources' was faced by $73.33 \%$ of the respondents and 'lack of accountancy management' was faced by $66.66 \%$ of the respondents. $58.88 \%$ of the respondents complained of the 'non-availability of credit', $55.55 \%$ of the respondents faced 'difficulty in raising finance'. $50.00 \%$ of the respondents found 'lack of command in the implementation of a decision', $43.33 \%$ of the respondents faced 'lack of marketing' and $33.33 \%$ of the respondents faced 'lack of coordination'. $31.11 \%$ of the respondents complained of 'tendency of others to underestimate a women's capability'. $27.77 \%$ of the respondents faced 'family problem'. $11.11 \%$ of the respondents found that there were 'problem of more competition and $7.77 \%$ of the respondents faced the problem of 'negative social attitude'.

From the study, it can be concluded that self help group members faced some constraints while performing their activities. High cost of input, non-availability of insurance, low market value were found to be most serious problem. Most of the SHG(s) in Manipur lack in proper flow of finance, limited market as well as lack in technical help. So immediate action is required to solve these problems and also the government need to focus on major problems faced by self help groups so as to make their resource mobilization meaningful and economic upliftment of members of self help groups.

\section{References}

Bhagyasree, P. (2014). A study on capacity building and empowerment of self help groups in Thane district of Maharashtra. M.Sc. (Agri) Thesis. Acharya N.G. Ranga Agricultural University, Hyderabad, India.

Bortamuly, D. And Khuhly, B.L. (2013). Constraints of self help groups in Assam. Journal of Academia and Industrial Research (JAIR). Vol.2, Issue 5.

Kaur, L. And Sachan, D. (2016). Evaluation of major problems faced by the members of self help groups: A study of Punjab. International Journal of Innovative Research in Science, Engineering and Technology. Vol.5, Issue 12.

Kumar, S.A. and Kavithasri, S. (2017). Problems faced by the members of self help groups with special reference to Thimmampalayam area in Coimbatore district. International Journal of Applied Research. 3(9): 593:598.

Kumawat, P. and Bansal, V. (2018). A study on problems faced by SHG members in carry out the SHG activities. International Journal of Current Microbiology and Applied Sciences. 7(1): 420-423.

Quadir, H. and Hussan, T. (2013). Empowerment of women through self help groups in Jammu and Kashmir.

$\begin{array}{llr}\text { International } & \text { Journal } \\ \text { Interdisciplinary } & \text { Research and }\end{array}$


Innovations, 1(1):22-25.

Rukhsana, Bose, K.D. and Singh, P.(2014). Constraints faced by rural women members in functioning of SHGs in Allahabad. International Journal of Students' Research in Technology and Management. Vol. 2 (05), pp 188-191.

Sadhu, K.G. 920130. A study on norms and functioning of self help groups (SHGs) in Punjab. Journal of Business Management and Social Sciences Research. Vol. 2, No. 8.

Simanowitz, Anton and Alice Walker. (2002). "Ensuring impact: reaching the poorest while building financially self-sufficient institutions and showing improvement in the lives of the poorest women and their families", unpublished paper for the Microcredit Summit + 5, New York, 1013 Nov, available at http://www.microcreditsummit,org/pape rs/papers.htm.

Zaman, H. (2001). "Assessing the poverty and vulnerability impact of micro-credit in Bangladesh: A case study of BRAC", unpublished background paper for World Bank, World Development Report 2000/2001 (Washington, World Bank).

\section{How to cite this article:}

Talsia Mangsidam, Aheibam Tarajit Singh and Geetu Thokchom. 2020. A Study on Constraints Faced by Self Help Groups in Imphal East District of Manipur. Int.J.Curr.Microbiol.App.Sci. 9(11): 1792-1796. doi: https://doi.org/10.20546/ijcmas.2020.911.212 